\title{
Information Presentation Pattern, Information Order and Framing Effect in Taking Investment Decisions
}

\author{
MOCHAMMAD ZAHID MUZAMMIL HADI \\ LUCIANA SPICA ALMILIA \\ RISKI APRILIA NITA \\ STIE Perbanas Surabaya
}

\begin{abstract}
This research aims to analyze which factors significantly influence the Earnings Response Coefficient (ERC). Sample of this research is including manufacturing companies listed in Indonesia Stock Exchange period 2012-2016. The sample is drawn using a purposive sampling method. There are 280 samples in total that are examined to conduct the study. Multiple regression analysis is used in this research to examine the hypotheses. Independent variables used in this research are earning persistence, profitability, leverage, growth opportunity, firm size, audit quality, CSR disclosure, and conservatism. The result of this research suggests that profitability and firm size have a significant and positive influence on Earning Response Coefficient. Result also shows earning persistence, and growth opportunity has a significant and negative influence on Earning Response Coefficient. Meanwhile, leverage, audit quality, CSR disclosure, and conservatism do not significantly influence the Earning Response Coefficient.
\end{abstract}

Keywords: Earning Response Coefficient; ERC; earning persistence; profitability; leverage; growth opportunity; firm size; audit quality; conservatism

Abstract: Penelitian ini bertujuan untuk menganalisa factor-faktor yang mempengaruhi Earnings Response Coefficient (ERC). Sampel penelitian ini adalah perusahaan manufaktur yang terdaftar dalam Bursa Efek Indonesian periode 2012 2016. Metoda pengambilan sampel dalam penelitian ini adalah purposive sampling method. Penelitian ini menggunakan sampel sebanyak 280 sampel. Analisis regresi berganda digunakan dalam penelitian ini untuk menguji hipotesis penelitian. Variabel independen dalam penelitian ini adalah persistensi laba, profitabilitas, leverage, growth opportunity, ukuran perusahaan, kualitas audit, pengungkapan CSR, dan konservatisma. Hasil penelitian ini menjunjukkan bahwa profitabilitas dan ukuran perusahaan berpengaruh positif terhadap Earning Response Coefficient. Hasil penelitian ini juga menunjukkan persistensi laba dan growth opportunity have memiliki pengaruh negatif terhadap Earning Response Coefficient. Sedangkan

*Corresponding author: lucy@perbanas.ac.id 
leverage, kualitas audit, pengungkapan CSR dan konservatisma tidak berpengaruh terhadap Earning Response Coefficient.

Kata Kunci: Earning Response Coefficient; persistensi laba; profitabilitas; leverage; growth opportunity; ukuran perusahaan; kualitas audit; konservatisma

\section{Introduction}

In making investment decisions, an investor needs a variety of information. Company performance information is information that must be known by investors in their investment decisions. It is as in accounting information that can be obtained through the company's financial statements. Accounting information only provides information that is material in nature, and often what investors pay attention to in financial statements is corporate profits. It shows that investors tend to focus on the current period only but not focus on business continuity or the company's prospects. If so, inevitably, there can be losses and inaccurate decision making for investors.

On the other hand, besides accounting information, another thing that investors must know is non-accounting information. As done in previous studies, Sharma (2006) proved that investor perceptions of the effectiveness of the board of directors are the main determinants of investment decisions. Also, Cox et al. (2004) also proved that institutional investors pay more attention to the company's corporate social responsibility report. The information presentation pattern developed by Hogarth and Einhorn (1992) in the belief adjustment model contained in this study is the step-bystep (SbS) information presentation pattern and the end-of-sequence (EoS) information presentation pattern. The step-by-step $(\mathrm{SbS})$ presentation pattern is the presentation of information that is carried out sequentially or consecutively so that the individual/investor forms a revision of new beliefs after obtaining pieces of evidence from separate information. Meanwhile, the end-of-sequence (EoS) information presentation pattern is the presentation of information carried out simultaneously or together so that individuals form a revision of new beliefs after all the information has been collected. 
Some previous studies (Pinsker, 2007 and Luciana Spica and Supriyadi, 2013) discussed something related to belief adjustment models. Pinsker (2007), from the results of his study, stated that the revision of stock prices is significantly greater under sequential conditions than it is under simultaneous conditions. Meanwhile, the results of research conducted by Luciana Spica and Supriyadi (2013) stated that there is a difference in judgment between investors who received an information order or good news followed by bad news (+ + - -) compared to investors who received an information order of bad news followed by good news $(--++)$ for the step-by-step information presentation pattern. Further, there is no difference or no sequence effect between investors who received an information order of good news followed by bad news $(++--)$ compared to investors who received an information order of bad news followed by good news $(--++)$ for the end-of-sequence information presentation pattern. In addition to the presentation pattern and information order, Yusnaini (2005), in his research, stated that the framing of information causes biases in strategic decision making. According to Erlinda Kusuma and Sukirno (2014), framing is a way to use language for the management of meaning. In framing effects, an event can result in decision-makers responding differently (with the same problem) is presented in different ways. Framing information (positive and negative frames) without changing the meaning of the information will be used to influence decision-makers. Chang et al. (2002), in his research, explained the framing effect using three theories, namely prospect theory, fuzzy trace theory, and probabilistic mental theory. They stated that the fuzzy-trace theory is the best in describing the phenomenon of framing effects on decision-making behavior.

\section{Theoretical Basis and Development of Hypothesis}

\subsection{Prospect Theory}

According to prospect theory, there are two stages in the decision-making process: Stage $\mathrm{I}$ is the editing stage, which is the initial analysis of the prospect offered. Then stage II is evaluating prospects and choosing the highest value (Kahneman and Tversky, 1979). Chang et al. (2002) stated that stage I of the prospect 
theory is the stage of the psychological editing process. In other words, prospect theory describes a person's reasons for making decisions in terms of his psychological side. Prospect theory refutes the previous theory, namely the expected utility theory that explains a person's rational decision making. Kahneman and Tversky (1979) also explained that the provision of information with a positive frame would influence decision-makers on less risky decision making (risk-averse) and vice versa if the provision of information is made with a negative frame. It will affect decision-makers in making riskier information (risk-seeking).

\subsection{Fuzzy Trace Theory}

Chang et al. (2002) explained the fuzzy trace theory introduced by Reyna and Brainerd (1990), which assumes that individuals prefer reasons by using simple representations of information. Fuzzy trace theory is closely related to the heuristic approach/strategy, which explains that decision-makers use the simplification process in making decisions. By using heuristics simplification, when a person is faced with a situation with risky choices or obtains complex information, the person will use a way to simplify the complexity of that information. Simplifying information means eliminating information complexity / using only information that is considered essential. Thus, it can be concluded that heuristics simplification will lead to bias in decision making because it reduces the complexity of the information used by decision-makers.

\subsection{Probabilistic Mental Theory}

Chang et al. (2002) explained probabilistic mental theories developed by Gigerenzer et al. (1991) that explain and predict the behavior of individuals who are too confident in decision making. Kuhberger (1995) suggested that probabilistic mental theories can be used to explain framing effects. Gigerenzer et al. (1991) explained that a person is faced with two choices. First, the local mental model that is used to solve problems based on long-term memory and basic logic operations will be formed by individuals. In general, local mental models can be used if (1) the right 
number can be taken from long-term memory to compare alternatives; (2) information features related to alternatives do not overlap and (3) basic logic operations. Second, if the problem cannot be solved directly using the local mental model, it will use a probabilistic mental model. According to the theory of probabilistic mental models, to make decisions, the first thing an individual does is to create a reference class for a specific problem. Gigerenzer et al. (1991) revealed that probabilistic mental models differ from local mental models in several aspects. First, it is in the reference class of the object. Second, the variables are added with strategy solutions.

\subsection{Presentation Pattern and Information Order}

Hogarth and Einhorn (1992) developed a belief adjustment model to provide a thorough explanation of the way information is interpreted and processed. Hogarth and Einhorn (1992) adapted the general concepts of anchoring and adjustment (such as forming initial beliefs which then form new beliefs based on new information obtained) by incorporating heuristics into the model. The belief adjustment model considers three characteristics, namely: (1) direction (whether it is following current belief or not), (2) strength (weak or strong), and (3) type (positive, negative, or mixed). Also, Hogarth and Einhorn (1992) also considered two other characteristics, namely the information order (positive followed by negative, positive-negative or a mixture of positive and negative) and presentation patterns (patterns of presentation in sequence and simultaneously). When information is presented in the form of step by step $(\mathrm{SbS})$, one generally uses a step-by-step $(\mathrm{SbS})$ processing strategy. Adjustment of their beliefs increases as each piece of evidence is given. Presentation of information in the form of end of the sequence (EoS) generally uses an end-of-sequence (EoS) processing strategy, especially if the amount of information is small and not too complicated. In the sequence of information, two possibilities will occur, namely the primacy effect and recency effect. The primacy effect is giving higher value to the initial information obtained so that an individual's final decision making depends on the initial information. In other words, in primacy effects, individuals tend to pay more attention or consider more the initial information they get. 
Meanwhile, the recency effect is giving higher value to the final information obtained so that an individual's final decision making depends on the final information. In other words, in the recency effect, individuals tend to pay more attention or consider more the final information they get. The potential of the recency effect will be greater in a step-by-step $(\mathrm{SbS})$ presentation because the end-of-sequence (EoS) evidence of positive and negative information is filtered before being integrated with previous beliefs.

\subsection{Framing Effect}

Framing is an event that results in decision-makers responding differently to the same problem if presented in different ways. Someone's use of language is an aspect of the frame used to influence decision-makers. Kahneman and Tversky (1979) stated that the provision of information with a positive frame would influence decisionmakers on decision making that is less risky (risk-averse) and vice versa if the provision of information with a negative frame will affect decision-makers on making riskier information (risk-seeking).

\subsection{Hypothesis Development}

In the belief adjustment theory, it is explained that for information / positive and negative evidence, there are two possible sequential effects, namely the primacy effect and the recency effect. When the pattern of step-by-step presentation (decision making after obtaining every piece of information evidence) is carried out in investment decision making, there will likely be a recency effect. For the end-of-sequence presentation pattern (decision making carried out after all information is collected), primacy effects tend to occur. Pinsker (2011) proved that (1) there is evidence that there is a recency effect giving long information cues in the investment context (2) sequential conditions can exacerbate the effect of the recency effect that is relative to simultaneous conditions. Based on these arguments, the research hypothesis to test the effect of information sequences is stated as follows: 
H1a. There are differences in investment decisions between subjects who receive an information order of good news followed by bad news (++ -) compared to subjects who receive an information order of bad news followed by good news $(-++)$ in the step-by-step pattern of presentation and with framing conditions following the information

H1b. There are differences in investment decisions between subjects who receive an information order of good news followed by bad news (++ -) compared to subjects who receive an information order of bad news followed by good news $(-++)$ in the step-by-step presentation pattern and with the framing conditions reversed

H1c. There are differences in investment decisions between subjects who receive an information order of good news followed by bad news (++ -) compared to subjects who receive an information order of bad news followed by good news $(-++)$ in the end-of-sequence presentation pattern and with the framing conditions in accordance with the information

H1d. There are differences in investment decisions between subjects who receive an information order of good news followed by bad news (++ -) compared to subjects who receive an information order of bad news followed by good news $(-++)$ in the end-of-sequence presentation pattern and with the framing conditions reversed

The framing effect is the framing of language or words without changing the meaning of information used to influence decision making, especially in investment decisions. In framing effects, an event can result in decision-makers responding differently (with the same problem) is presented in different ways. Muhammad Nur and Jen Surya (2012) also stated that the framing effect is influential as a determinant of commitment escalation. With this argument, the research hypothesis to test the framing effect is stated as follows:

H2a. There is a difference in investment decisions between subjects who receive information with framing conditions in accordance with the information compared to subjects who receive framing that is reversed in the step-by-step presentation pattern and in the information order of good news followed by bad news (++ -) 
H2b. There is a difference in investment decisions between subjects who receive information with framing conditions in accordance with the information compared to subjects who receive framing that is reversed in the step-by-step presentation pattern and the information order of bad news followed by good news (- ++)

H2c. There is a difference in investment decisions between subjects who receive information with framing conditions in accordance with the information compared to subjects who receive framing that is reversed in the end-of-sequence presentation pattern and the information order of good news followed by bad news (++ -)

H2d. There is a difference in investment decisions between subjects who receive information with the framing conditions in accordance with the information compared to subjects who receive framing that is reversed in the end-of-sequence presentation pattern and the information order of bad news followed by good news (- ++)

This experimental research uses the information presentation pattern developed by Hogarth and Einhorn (1992) in the belief adjustment model, namely the step-bystep (SbS) information presentation pattern and the end-of-sequence information presentation pattern (EoS) in investment decision making. Luciana Spica et al. (2013) proved that it is proven that there was an effect of information order in making investment decisions for the information presented sequentially / step by step. Further, there is no effect of information order in making investment decisions for information that is presented simultaneously / end of the sequence. With this argument, the research hypothesis to test the framing effect is stated as follows:

H3a. There is a difference in investment decisions between subjects who receive information with a step-by-step presentation pattern compared to subjects who receive information with end-of-sequence presentation patterns in the information order of good news followed by bad news (++ -) and with framing conditions in accordance with the information

H3b. There is a difference in investment decisions between subjects who receive information with a step-by-step presentation pattern compared to subjects who receive information with an end-of-sequence presentation pattern in the information order of 
bad news followed by good news $(-++)$ and with framing conditions in accordance with the information

H3c. There is a difference in investment decisions between subjects who receive information with a step-by-step presentation pattern compared to subjects who receive information with end-of-sequence presentation patterns in the information order of good news followed by bad news (++ -) and with the framing conditions reversed

H3d. There is a difference in investment decisions between subjects who receive information with a step-by-step presentation pattern compared to subjects who receive information with an end-of-sequence presentation pattern in the information order of bad news followed by good news (- ++) and with the framing conditions reversed The scheme of this research framework is as follows:

Figure 1

\section{FRAMEWORK OF THOUGHT}

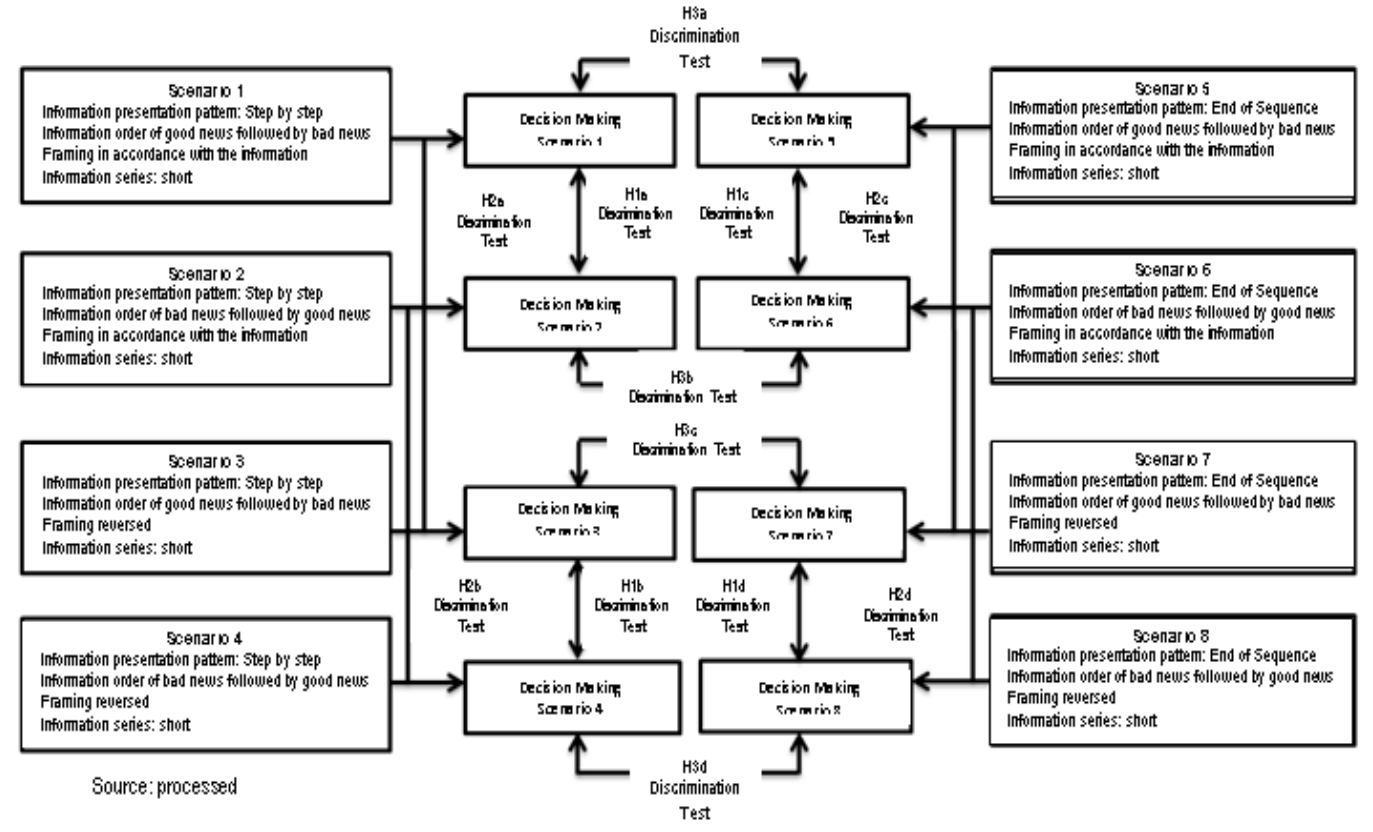

\section{Research Method}

\subsection{Research Design}

This research is research that used an experimental method. According to Ertambang Nahartyo (2012), an experiment is a research design to investigate a 
phenomenon by manipulating conditions or circumstances through specific procedures and then observing the results of the engineering and interpreting them. In this experimental study, the researcher manipulated one or more independent variables to see changes in the dependent variable in response to the manipulation of the independent variable. This study used primary data obtained from the students of Bachelor of Accounting and Bachelor of Management at STIE Perbanas Surabaya who were taking/have taken Financial Statement Analysis (ALK) and/or Investment and Capital Market Management (MIPM) courses. This study used a 2×2x2 mixed design, which meant that this experimental research used two levels of information presentation patterns (step by step and end of the sequence), two levels of information sequence (++ - and - ++) and two levels of framing effects. (Framing in accordance with the information and framing reversed).

\subsection{Variable Identification}

Based on the research hypothesis, the variables contained in this study included the dependent variable and the independent variable. The dependent variable in this study was the investment decision. Meanwhile, the independent variables in this study included: (1) The step-by-step (SbS) and end-of-sequence (EoS) pattern of information presentation; (2) Information order of good news followed by bad news and bad news followed by good news (++ - and - ++); (3) Framing effect (framing in accordance with the information and framing reversed)

\subsection{Research Participant}

Participants in this experimental research were students majoring in Bachelor of Accounting and Bachelor of Management at STIE Perbanas Surabaya, who knew about finance and investment. The sampling technique used was purposive sampling, namely sampling, by providing specific criteria. The criteria for selected participants were students who were taking/have taken one or all of the following courses: (1) Financial Statement Analysis (students of Bachelor of Accounting and Bachelor of Management), (2) Investment and Capital Market Management (students of Bachelor of Accounting), and (3) Investment and Portfolio Management (students of Bachelor Management). 


\subsection{Experiment Procedure}

In this experimental study, researchers used a pencil base experiment that was done using a questionnaire answered by participants manually. Participants in this study were asked to assume the role of investors who were assessing company performance based on information on the company. This experimental research consisted of eight scenarios. Participants in this experimental study would carry out one of the eight scenarios chosen randomly, namely:

1. Scenario 1: participants would receive non-accounting information with framing in accordance with the information in the step-by-step presentation pattern and the information order of good news followed by bad news (++ -).

2. Scenario 2: participants would receive non-accounting information with framing in accordance with the information in the step-by-step presentation pattern and the information order of bad news followed by good news $(-++)$.

3. Scenario 3: Participants would receive non-accounting information with information framing reversed in a step-by-step presentation pattern and the information order of good news followed by bad news (++ -).

4. Scenario 4: Participants would receive non-accounting information with information framing reversed in a step-by-step presentation pattern and the information order of bad news followed by good news $(-++)$.

5. Scenario 5: participants would receive non-accounting information with framing in accordance with the information in the end-of-sequence presentation pattern and the information order of good news followed by bad news (++ -).

6. Scenario 6: participants would receive non-accounting information with framing in accordance with the information in the end-of-sequence presentation pattern and in the information order of bad news followed by bad news (--++)

7. Scenario 7: participants would receive non-accounting information with information framing reversed in the end-of-sequence presentation pattern and in the information order of good news followed by bad news (++--) 
8. Scenario 8: participants would receive non-accounting information with information framing reversed in the end-of-sequence presentation pattern and in the information order of bad news followed by good news (--++).

The participants' task was to assess the shares of PT MNS Tbk, a company engaged in the business of natural gas transmission and distribution. PT MNS Tbk was founded in 1859 under the name SKL, and then on May 13, 1965, it changed its name to MNS. Finally, on December 15, 2003, the MNS Company was listed on the Indonesia Stock Exchange (IDX) and changed its name to PT MNS Tbk. Company shares were taken from examples of actual companies listed on the Indonesia Stock Exchange (IDX). The researcher was free to choose a hypothetical company (fiction) because, in this study, the researcher was not given any restrictions in choosing a hypothetical company (fiction).

Subjects were asked to reassess the value of shares for non-accounting information and the information presentation pattern (step by step and end of the sequence) with an initial value of company shares of Rp. 6,000.00 and provides a scale for each disclosure with a multiple of -1000 (very bad news) and +1000 (very good news). The procedure carried out by the subject in reassessing stocks based on the information presentation pattern (step by step and end of the sequence) is illustrated in the following table:

Table 1

PROCEDURE CARRIED OUT BY THE SUBJECT BASED ON THE PATTERN OF INFORMATION PRESENTATION

\begin{tabular}{|c|l|l|}
\hline \multicolumn{2}{|c|}{ The Pattern of Information Presentation } \\
\hline $\begin{array}{c}\text { No } \\
1\end{array}$ & $\begin{array}{c}\text { Step by Step } \\
\text { Read the company background }\end{array}$ & $\begin{array}{l}\text { End of Sequence } \\
\text { Read the company background }\end{array}$ \\
2 & $\begin{array}{l}\text { Information about the initial value of a } \\
\text { company's stock was given. With an initial } \\
\text { stock value of Rp. 6,000.00 }\end{array}$ & $\begin{array}{l}\text { Information about the initial value of a } \\
\text { company's stock was given. With an } \\
\text { initial stock value of Rp. 6,000.00 }\end{array}$ \\
3 & Non-accounting information, with framing & Non-accounting information with framing \\
\hline
\end{tabular}




\begin{tabular}{|l|l|l|}
\hline & $\begin{array}{l}\text { in accordance with information as many as } \\
\text { eight items, consisting of four good news } \\
\text { information and four bad news } \\
\text { information. Non-accounting information, } \\
\text { with framing, reversed as many as eight } \\
\text { items, consisting of four good news } \\
\text { information and four bad news } \\
\text { information, were given. }\end{array}$ & $\begin{array}{l}\text { in information and four bad news } \\
\text { information and non-accounting } \\
\text { information with framing reversed as } \\
\text { many as eight items consisting of four } \\
\text { good news information and four bad news } \\
\text { information were given. }\end{array}$ \\
5 & $\begin{array}{l}\text { Assess the value of the company's shares } \\
\text { eight times (for each evidence provided) }\end{array}$ & $\begin{array}{l}\text { Assess the value of the company's shares } \\
\text { once (when the subject has received all } \\
\text { non-accounting report information) }\end{array}$ \\
$\begin{array}{l}\text { Subjects were asked to respond to } \\
\text { manipulation check questions and } \\
\text { questions to measure the subject's basic } \\
\text { abilities in the area of financial statement } \\
\text { analysis and/or investment and capital } \\
\text { markets management and/or investment } \\
\text { and portfolio management and fill in } \\
\text { participant demographic items. }\end{array}$ & $\begin{array}{l}\text { Subjects were asked to respond to } \\
\text { manipulation check questions and } \\
\text { questions to measure the subject's basic } \\
\text { abilities in the area of financial statement } \\
\text { analysis and/or investment and capital } \\
\text { markets management and/or investment } \\
\text { and portfolio management and fill in } \\
\text { participant demographic items. }\end{array}$ \\
$\begin{array}{l}\text { Debriefing session } \\
\text { Debriefing session }\end{array}$
\end{tabular}

The debriefing session is the process of restoring the subject's condition before entering the assignment in the experiment and allowing the research subject to give honest comments about the conduct of the experiment (Christensen, 1988). A debriefing session was conducted after participants participated in assignments in this experimental research. The researcher also informed the purpose of the experiment directly and requested from participants responses related to the assignment of experiments through the media presentation directly and asked participants not to discuss any matters related to the experimental assignment. This study used eight pieces of information taken from the report on the implementation of corporate governance and corporate social responsibility, which consisted of four pieces of positive information (good news) and four pieces of negative information (bad news).

This study used eight pieces of information taken from the report on the implementation of corporate governance and corporate social responsibility, which 
consist of four pieces of positive information (good news) and four pieces of negative information (bad news). Good news and bad news information were stated as follows:

Four pieces of good news information are as follow:

1. There was a $70 \%$ possibility in June 2015 that the company transparently submitted a report on the implementation of the audit committee's activities and the attendance of the audit committee meeting.

2. There was a $70 \%$ chance in June 2015 that the company was able to process 19 tons of B3 waste properly.

3. There was a $70 \%$ chance in June 2015 that the company was able to manage the environment and forestry well.

4. There was a $70 \%$ chance in June 2015 that the company was paying attention to the world of education, which was related to the construction and renovation of schools around the operational area.

Table 2

HYPOTHESIS TESTING CELL

\begin{tabular}{|c|c|c|c|c|}
\hline \multirow{2}{*}{$\begin{array}{c}\text { Information } \\
\text { Type }\end{array}$} & Framing Effect & $\begin{array}{c}\text { Information } \\
\text { Order }\end{array}$ & \multicolumn{2}{|c|}{ Information Presentation Pattern } \\
\cline { 4 - 5 } & $\begin{array}{c}\text { Framing in } \\
\text { accordance with } \\
\text { the information }\end{array}$ & ++-- & Cell 1 & Cequence \\
\hline $\begin{array}{c}\text { Non- } \\
\text { Accounting }\end{array}$ & Framing reversed & -++ & Cell 2 & Cell 6 \\
& Fell 3 & Cell 7 \\
\hline
\end{tabular}

\section{Hypothesis Testing Result and Discussion}

\subsection{Demographic Data and Manipulation Checks}

Criteria for subjects in this study were the students of Bachelor of Accounting and Bachelor of Management who had the knowledge in investment and capital markets and financial statement analysis. The difference in majors between Bachelor Accounting and Bachelor of Management was not the benchmark in the selection of 
research participants. However, the researchers paid more attention to the courses they had taken and were taking, namely Financial Statement Analysis and or Investment and Capital Market Management (for Bachelor of Accounting) or Portfolio Investment Management (for Bachelor of Management students). The number of subjects who were willing to become research participants was one hundred and twelve (112) students consisting of ninety-six (96) undergraduate students majoring in Accounting and sixteen (16) undergraduate students majoring in Management. One hundred and twelve (112) subjects filled in the experimental instruments in a specified time limit. Manipulation check was used to determine whether the experimental assignments given had been known, understood, and responded by the subjects correctly. The subjects could be considered "pass" if they met the criteria set by the previous researchers. The criteria for subjects that can be considered "pass" and can be further processed are as follows:

1. The subject can answer manipulation check at least one question correctly;

2. Subjects can answer general knowledge questions at least one question correctly;

3. Subjects can fill up and finish all assignments.

This criterion was a reference for researchers to determine whether the subject can be considered to pass or not. For subjects who had the best score in conducting experimental assignments would get a reward of 50,000 IDR. The purpose of this reward was to encourage subjects to take part in the assignment well and to appreciate the participation of subjects in taking the assignment of experiments. There were eight (8) subjects that cannot be processed further because they did not pass the manipulation check and / or were unable to answer common questions. Thus the total number of subjects who passed and can be further processed was one hundred and four (104) subjects.

\subsection{Instrument Execution Chronology}

\subsubsection{Preparation}


The implementation of this research began with the search for participants who were willing to become research participants. Participants were selected by (1) approaching a group of familiar people who were gathering in a group, (2) visiting familiar people who were going in and out of campus or classrooms, and (3) inviting friends through personal chatting via mobile phones. Also, the selection of participants was also made by using the lures such as (1) there would be a reward of $50.000 \mathrm{IDR}-$ per participant for the ten best participants who answered according to researchers' criteria (namely completing all assignments in instrument and having the best score in the assignment); (2) participants would get refreshment and (3) there would be input to participants so that after completion of research participants can have quality time with friends. The evidence that participants were willing to become experimental research participants was by signing an informed consent form on December 3, 2016.

\subsubsection{Execution}

The research was carried out on Saturday, December 3, 2016. All participants who had signed an informed consent form were gathered in a room to fill in the research instrument. Participants were gathered in rooms IIB302, IIB403, IIB404, and IIB405 on campus 2 of STIE Perbanas Surabaya. The number of participants who attended was 112 participants. This number did not match the number of participants who signed an informed consent form because as many as 8 participants did not attend the session. The execution was considered delayed from the predetermined schedule because many participants were late. It was originally scheduled at 10:00 WIB, but it was carried out at 10.15 WIB. Regardless, the execution went smoothly.

\subsubsection{Obstacles}

The execution of this experimental assignment encountered several obstacles in the field. First, it was challenging to find participants because the day of the experiment execution was Saturday, and many participants joined organizational activities happening at the same time. However, this could be overcome by the researchers quickly and responsively. Second, the assignments could not be carried out on time in 
accordance with the predetermined schedule because the researchers had to wait for most of the participants who arrived late. As a result, the assignment execution was 15 minutes late from the predetermined schedule, and hence the execution began at 10.15 WIB. Third, some participants were not as the ones listed in the confirmation of attendance and who made a sudden participation cancellation because they had other sudden businesses that could not be left behind. As a result, the researchers had to find substitutes who were willing to be research participants immediately. Fourth, the limited human resources caused some classes to be ineffective. It was because the facilitator had to carry out two responsibilities at the same time, namely guiding the activity and being a timekeeper. In addition, the researchers who were in charge of being an assessor also faced difficulty and had to assess the participants' responses quickly and thoroughly. It was because three researchers who were assigned to work as assessors had to assess the works from 6 classes, meaning that each researcher had to assess two classes altogether. However, this could all be overcome by facilitators and assessors.

\subsubsection{Testing the Effect of the Pattern of Information Presentation, Information Order} and Framing Effects on Investment Decision Making

This study examined the effect of the information presentation pattern, information order, and framing effects on investment decision making using non-accounting information on short information series ( $<12$ pieces of information). The normality test results are as follows

Table 3

NORMALITY TESTING RESULTS

\begin{tabular}{|c|c|c|c|}
\hline \multirow{2}{*}{ Testing } & \multicolumn{2}{|c|}{ Value } & \multirow{2}{*}{ Notes } \\
\cline { 2 - 3 } & $\mathbf{Z}$ & Sig & \\
\hline Cell 1 with cell 2 & 0,607 & 0,855 & Normal \\
Cell 3 with cell 4 & 0,623 & 0,833 & Normal \\
Cell 5 with cell 6 & 1,531 & 0,018 & Abnormal \\
Cell 7 with cell 8 & 1,213 & 0,106 & Normal \\
Cell 1 with cell 3 & 0,765 & 0,602 & Normal \\
Cell 2 with cell 4 & 0,722 & 0,674 & Normal \\
\hline
\end{tabular}




\begin{tabular}{|c|c|c|c|}
\hline Cell 5 with cell 7 & 1,099 & 0,178 & Normal \\
Cell 6 with cell 8 & 1,563 & 0,015 & Abnormal \\
Cell 1 with cell 5 & 1,120 & 0,162 & Normal \\
Cell 2 with cell 6 & 0,976 & 0,297 & Normal \\
Cell 3 with cell 7 & 0,569 & 0,903 & Normal \\
Cell 4 with cell 8 & 1,214 & 0,105 & Normal \\
\hline
\end{tabular}

Based on the table above, it can be seen that the Kolmogorov-Smirnov test value of all tests on the final judgment of participants is only two tests that are not normally distributed, namely testing cell 5 with cell 6 and testing cell 6 with cell 8 . This is because the significance value is less than 0.05. Apart from the two tests, the data are normally distributed because they have a significance value of more than 0.05 . For normally distributed data, a test using an independent sample t-test will be carried out. Meanwhile, for data that are not normally distributed, a test using the Mann Whitney $u$ test will be performed.

Based on the test results below, it can be concluded that hypothesis 1a, hypothesis $2 \mathrm{a}$, hypothesis $2 \mathrm{~b}$, hypothesis $3 \mathrm{a}$, and hypothesis $3 \mathrm{~b}$ are declared supported. Thus, hypotheses 1a, 2a, 2b, 3a, and $3 \mathrm{~b}$ are consistent with the theory used by the researchers, namely prospect theory, fuzzy trace theory, and probabilistic mental theory. However, different from the hypothesis 1b, hypothesis 1d, hypothesis 2c, hypothesis $3 \mathrm{c}$, and hypothesis $3 \mathrm{~d}$ are declared unsupported. As this hypothesis is not supported, it is not consistent with the theory used by the researchers.

Tabel 4

TESTING RESULT OF INDEPENDENT SAMPLE T-TEST

\begin{tabular}{|c|c|c|c|c|c|c|}
\hline Hypothesis & Testing & $\begin{array}{c}\text { Presentation } \\
\text { Pattern }\end{array}$ & $\begin{array}{c}\text { Evidence } \\
\text { Order }\end{array}$ & Framing & Mean & $\begin{array}{l}\text { Sig. 2- } \\
\text { tailed }\end{array}$ \\
\hline $1 \mathrm{a}$ & $\begin{array}{l}\text { Cell } 1 \\
\text { Cell } 2\end{array}$ & $\begin{array}{l}\text { Step by step } \\
\text { Step by step }\end{array}$ & $\begin{array}{l}++-- \\
--++\end{array}$ & $\begin{array}{l}\text { In accordance } \\
\text { with the } \\
\text { information } \\
\text { In accordance } \\
\text { with the } \\
\text { information }\end{array}$ & $\begin{array}{l}3733,33 \\
8933,33\end{array}$ & 0,000 \\
\hline $1 b$ & $\begin{array}{l}\text { Cell } 3 \\
\text { Cell } 4\end{array}$ & $\begin{array}{l}\text { Step by step } \\
\text { Step by step }\end{array}$ & $\begin{array}{l}++-- \\
--++\end{array}$ & $\begin{array}{l}\text { Reversed } \\
\text { Reversed }\end{array}$ & $\begin{array}{l}5714,29 \\
5666,67\end{array}$ & 0,965 \\
\hline
\end{tabular}




\begin{tabular}{|c|c|c|c|c|c|c|}
\hline $1 d$ & $\begin{array}{l}\text { Cell } 7 \\
\text { Cell } 8\end{array}$ & $\begin{array}{c}\text { End of } \\
\text { sequence } \\
\text { End of } \\
\text { sequence }\end{array}$ & $\begin{array}{l}++-- \\
--++\end{array}$ & $\begin{array}{l}\text { Reversed } \\
\text { Reversed }\end{array}$ & $\begin{array}{c}5400 \\
5916,67\end{array}$ & 0,477 \\
\hline $2 a$ & $\begin{array}{l}\text { Cell } 1 \\
\text { Cell } 3\end{array}$ & $\begin{array}{l}\text { Step by step } \\
\text { Step by step }\end{array}$ & $\begin{array}{l}++-- \\
++--\end{array}$ & $\begin{array}{l}\text { In accordance } \\
\text { with the } \\
\text { information } \\
\text { Reversed }\end{array}$ & $\begin{array}{l}3733,33 \\
5714,29\end{array}$ & 0,037 \\
\hline $2 b$ & $\begin{array}{l}\text { Cell } 2 \\
\text { Cell } 4\end{array}$ & $\begin{array}{l}\text { Step by step } \\
\text { Step by step }\end{array}$ & $\begin{array}{l}--++ \\
--++\end{array}$ & $\begin{array}{c}\text { In accordance } \\
\text { with the } \\
\text { information } \\
\text { Reversed }\end{array}$ & $\begin{array}{l}8933,33 \\
5666,67\end{array}$ & 0,000 \\
\hline $2 c$ & $\begin{array}{l}\text { Cell } 5 \\
\text { Cell } 7\end{array}$ & $\begin{array}{c}\text { End of } \\
\text { sequence } \\
\text { End of } \\
\text { sequence }\end{array}$ & $\begin{array}{l}++-- \\
++--\end{array}$ & $\begin{array}{l}\text { In accordance } \\
\text { with the } \\
\text { information } \\
\text { Reversed }\end{array}$ & $\begin{array}{c}5384,61 \\
5400\end{array}$ & 0,980 \\
\hline $3 a$ & $\begin{array}{l}\text { Cell } 1 \\
\text { Cell } 5\end{array}$ & $\begin{array}{l}\text { Step by step } \\
\text { End of } \\
\text { sequence }\end{array}$ & $\begin{array}{l}++-- \\
++--\end{array}$ & $\begin{array}{l}\text { In accordance } \\
\text { with the } \\
\text { information } \\
\text { In accordance } \\
\text { with the } \\
\text { information }\end{array}$ & $\begin{array}{l}3733,33 \\
5384,61\end{array}$ & 0,012 \\
\hline $3 b$ & $\begin{array}{l}\text { Cell } 2 \\
\text { Cell } 6\end{array}$ & $\begin{array}{l}\text { Step by step } \\
\text { End of } \\
\text { sequence }\end{array}$ & $\begin{array}{l}--++ \\
--++\end{array}$ & $\begin{array}{l}\text { In accordance } \\
\text { with the } \\
\text { information } \\
\text { In accordance } \\
\text { with the } \\
\text { information }\end{array}$ & $\begin{array}{c}8933,33 \\
6000\end{array}$ & 0,000 \\
\hline $3 c$ & $\begin{array}{l}\text { Cell } 3 \\
\text { Cell } 7\end{array}$ & $\begin{array}{c}\text { Step by step } \\
\text { End of } \\
\text { sequence }\end{array}$ & $\begin{array}{l}++-- \\
++--\end{array}$ & $\begin{array}{l}\text { Reversed } \\
\text { Reversed }\end{array}$ & $\begin{array}{c}5714,29 \\
5400\end{array}$ & 0,764 \\
\hline $3 d$ & $\begin{array}{l}\text { Cell } 4 \\
\text { Cell } 8\end{array}$ & $\begin{array}{l}\text { Step by step } \\
\text { End of } \\
\text { sequence }\end{array}$ & $\begin{array}{l}--++ \\
--++\end{array}$ & $\begin{array}{l}\text { Reversed } \\
\text { Reversed }\end{array}$ & $\begin{array}{l}5666,67 \\
5916,67\end{array}$ & 0,778 \\
\hline
\end{tabular}

Tabel 5

TESTING RESULT OF MANN WHITNEY U TEST

\begin{tabular}{|c|c|c|c|c|c|c|}
\hline Hypothesis & Testing & $\begin{array}{c}\text { Presentation } \\
\text { Pattern }\end{array}$ & $\begin{array}{c}\text { Evidence } \\
\text { Order }\end{array}$ & Framing & Mean & $\begin{array}{c}\text { Sig. 2- } \\
\text { tailed }\end{array}$ \\
\hline 1c & $\begin{array}{c}\text { Cell 5 } \\
\text { Cell 6 }\end{array}$ & $\begin{array}{c}\text { End of } \\
\text { sequence } \\
\text { End of } \\
\text { sequence }\end{array}$ & $\begin{array}{c}\text { In accordance } \\
\text { with the } \\
\text { information } \\
\text { In accordance } \\
\text { with the } \\
\text { information }\end{array}$ & $\begin{array}{c}5384,61 \\
6000\end{array}$ & 0,127 \\
\hline 2d & Cell 6 & $\begin{array}{c}\text { End of } \\
\text { Sequence } \\
\text { End of }\end{array}$ & $\begin{array}{c}--++ \\
--++\end{array}$ & $\begin{array}{c}\text { In accordance } \\
\text { with the } \\
\text { information }\end{array}$ & 5916,67 & 0,839 \\
\hline
\end{tabular}




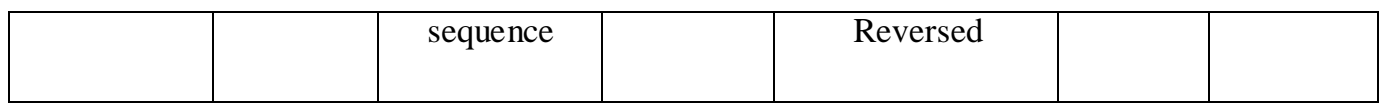

Source: processed using SPSS 21

Based on the test results above, it can be concluded that hypothesis $1 \mathrm{c}$ and hypothesis $2 \mathrm{~d}$ are declared unsupported. This means that this hypothesis is not consistent with the theory used by the researchers.

4.2.5. Discussion on the Effect of Information Presentation Patterns, Information Order and Framing Effects on Investment Decision Making

Table 6

HYPOTHESIS TESTING RESULTS USING INDEPENDENT SAMPLE T-TEST

\begin{tabular}{|c|c|c|c|c|c|c|c|c|}
\hline Testing & Hypothesis & $\begin{array}{c}\text { Presentation } \\
\text { Pattern }\end{array}$ & $\begin{array}{c}\text { Evidence } \\
\text { Order }\end{array}$ & Framing & Mean & Results & $\mathbf{T}$ & Sig. \\
\hline \multirow{3}{*}{$\begin{array}{l}\text { Information } \\
\text { order } \\
\text { testing }\end{array}$} & $1 \mathrm{a}$ & $\begin{array}{l}\text { Cell } 1-\text { SbS } \\
\text { Cell 2-SbS }\end{array}$ & $\begin{array}{l}\text { ++-- } \\
--++\end{array}$ & $\begin{array}{c}\text { In } \\
\text { accordance } \\
\text { with the } \\
\text { information } \\
\text { In } \\
\text { accordance } \\
\text { with the } \\
\text { information }\end{array}$ & $\begin{array}{l}3.733,33 \\
8.933,33\end{array}$ & $\begin{array}{l}\text { Recency } \\
\text { Effect }\end{array}$ & $\begin{array}{c}- \\
8,132\end{array}$ & 0,000 \\
\hline & $1 \mathrm{~b}$ & $\begin{array}{l}\text { Cell } 3-\text { SbS } \\
\text { Cell 4-SbS }\end{array}$ & $\begin{array}{l}++-- \\
--++\end{array}$ & $\begin{array}{l}\text { Reversed } \\
\text { Reversed }\end{array}$ & $\begin{array}{l}5.714,29 \\
5.666,67\end{array}$ & $\begin{array}{l}\text { No Order } \\
\text { Effect }\end{array}$ & 0,044 & 0,965 \\
\hline & $1 \mathrm{~d}$ & $\begin{array}{l}\text { Cell } 7 \text { - EoS } \\
\text { Cell } 8-\text { EoS }\end{array}$ & $\begin{array}{l}++-- \\
--++\end{array}$ & $\begin{array}{l}\text { Reversed } \\
\text { Reversed }\end{array}$ & $\begin{array}{c}5.400 \\
5.916,67\end{array}$ & $\begin{array}{l}\text { No Order } \\
\text { Effect }\end{array}$ & $\begin{array}{c}- \\
0,726\end{array}$ & 0,477 \\
\hline \multirow{2}{*}{$\begin{array}{l}\text { Framing } \\
\text { effect } \\
\text { testing }\end{array}$} & $2 a$ & $\begin{array}{l}\text { Cell } 1-\text { SbS } \\
\text { Cell } 3-\mathrm{SbS}\end{array}$ & $\begin{array}{l}\text { ++-- } \\
\text { ++-- }\end{array}$ & $\begin{array}{c}\text { In } \\
\text { accordance } \\
\text { with the } \\
\text { information } \\
\text { Reversed }\end{array}$ & $\begin{array}{l}3.733,33 \\
5.714,29\end{array}$ & $\begin{array}{l}\text { Stuck in } \\
\text { framing }\end{array}$ & 2,191 & 0,037 \\
\hline & $2 \mathrm{~b}$ & $\begin{array}{l}\text { Cell 2-SbS } \\
\text { Cell 4-SbS }\end{array}$ & $\begin{array}{l}--++ \\
--++\end{array}$ & $\begin{array}{c}\text { In } \\
\text { accordance } \\
\text { with the } \\
\text { information } \\
\text { Reversed }\end{array}$ & $\begin{array}{l}8.933,33 \\
5.666,67\end{array}$ & $\begin{array}{l}\text { Stuck in } \\
\text { framing }\end{array}$ & 4,028 & 0,000 \\
\hline
\end{tabular}




\begin{tabular}{|c|c|c|c|c|c|c|c|c|}
\hline & $2 c$ & $\begin{array}{l}\text { Cell } 5 \text { - EoS } \\
\text { Cell } 7 \text { - EoS }\end{array}$ & $\begin{array}{l}++- \\
++-\end{array}$ & $\begin{array}{c}\text { In } \\
\text { accordance } \\
\text { with the } \\
\text { information } \\
\text { Reversed }\end{array}$ & $\begin{array}{c}5.384,61 \\
5.400\end{array}$ & $\begin{array}{c}\text { Not stuck } \\
\text { in } \\
\text { framing }\end{array}$ & $\overline{-}, 025$ & 0,980 \\
\hline \multirow{4}{*}{$\begin{array}{c}\text { Testing on } \\
\text { information } \\
\text { presentation } \\
\text { pattern }\end{array}$} & $3 a$ & $\begin{array}{l}\text { Cell } 1-\text { SbS } \\
\text { Cell } 5 \text { - EoS }\end{array}$ & $\begin{array}{l}++-- \\
++-\end{array}$ & $\begin{array}{c}\text { In } \\
\text { accordance } \\
\text { with the } \\
\text { information } \\
\text { In } \\
\text { accordance } \\
\text { with the } \\
\text { information }\end{array}$ & $\begin{array}{l}3.733,33 \\
5.384,61\end{array}$ & $\begin{array}{l}\text { There is a } \\
\text { difference }\end{array}$ & $\begin{array}{c}- \\
2,694\end{array}$ & 0,012 \\
\hline & $3 b$ & $\begin{array}{l}\text { Cell 2-SbS } \\
\text { Cell 6-EoS }\end{array}$ & $\begin{array}{l}--++ \\
--++\end{array}$ & $\begin{array}{c}\text { In } \\
\text { accordance } \\
\text { with the } \\
\text { information } \\
\text { In } \\
\text { accordance } \\
\text { with the } \\
\text { information }\end{array}$ & $\begin{array}{c}8.933,33 \\
6.000\end{array}$ & $\begin{array}{l}\text { There is a } \\
\text { difference }\end{array}$ & 5,762 & 0,000 \\
\hline & $3 c$ & $\begin{array}{l}\text { Cell } 3 \text { - SbS } \\
\text { Cell } 7 \text { - EoS }\end{array}$ & $\begin{array}{l}++- \\
++--\end{array}$ & $\begin{array}{l}\text { Reversed } \\
\text { Reversed }\end{array}$ & $\begin{array}{c}5.714,29 \\
5.400\end{array}$ & $\begin{array}{l}\text { There is } \\
\text { no } \\
\text { difference }\end{array}$ & 0,304 & 0,764 \\
\hline & $3 d$ & $\begin{array}{l}\text { Cell } 4-\text { SbS } \\
\text { Cell } 8-\text { EoS }\end{array}$ & $\begin{array}{l}--++ \\
--++\end{array}$ & $\begin{array}{l}\text { Reversed } \\
\text { Reversed }\end{array}$ & $\begin{array}{l}5.666,67 \\
5.916,67\end{array}$ & $\begin{array}{l}\text { There is } \\
\text { no } \\
\text { difference }\end{array}$ & $0, \overline{285}$ & 0,778 \\
\hline
\end{tabular}

Table 7

HYPOTHESIS TESTING RESULTS USING MANN WHITNEY U TEST

\begin{tabular}{|c|c|c|c|c|c|c|c|}
\hline Testing & Hypothesis & $\begin{array}{c}\text { Presentation } \\
\text { pattern }\end{array}$ & $\begin{array}{c}\text { Evidence } \\
\text { Order }\end{array}$ & Framing & Mean & Results & Sig. \\
\hline $\begin{array}{c}\text { Information } \\
\text { order } \\
\text { testing }\end{array}$ & 1c & Cell 5-EoS & ++-- & $\begin{array}{c}\text { In } \\
\text { accordance } \\
\text { with the } \\
\text { information }\end{array}$ & $5.384,61$ & $\begin{array}{c}\text { No } \\
\text { Order } \\
\text { Effect }\end{array}$ & 0,127 \\
\hline
\end{tabular}




\begin{tabular}{|c|c|c|c|c|c|c|c|}
\hline & & & & information & & & \\
\hline $\begin{array}{c}\text { Framing } \\
\text { effect } \\
\text { testing }\end{array}$ & $2 d$ & $\begin{array}{l}\text { Cell 6-EoS } \\
\text { Cell } 8 \text { - EoS }\end{array}$ & $\begin{array}{c}--++ \\
--++\end{array}$ & $\begin{array}{l}\text { In } \\
\text { accordance } \\
\text { with the } \\
\text { information } \\
\text { Reversed }\end{array}$ & $\begin{array}{c}6.000 \\
5.916,67\end{array}$ & $\begin{array}{c}\text { Not } \\
\text { stuck in } \\
\text { framing }\end{array}$ & 0,839 \\
\hline
\end{tabular}

Hypothesis 1a testing results show that there is a significant difference in the final judgment between subjects who received the information order of good news followed by bad news (cell 1) and subjects who received the information order of bad news followed by good news (cell 2) in the step-by-step presentation pattern and in the framing conditions in accordance with the information. This supported condition is strengthened by the indication of the fishtail pattern in the revision of participants' beliefs. Hypothesis 1a results show that there are differences in investment decisions. So, the endpoint of the fishtail pattern for hypothesis 1a shows a far endpoint.

Figure 2

FISHTAIL PATTERNS IN THE REVISION OF CONFIDENCE TAKEN BY INVESTORS ON STEP-BY-STEP PRESENTATION PATTERNS IN INFORMATION ORDER TES

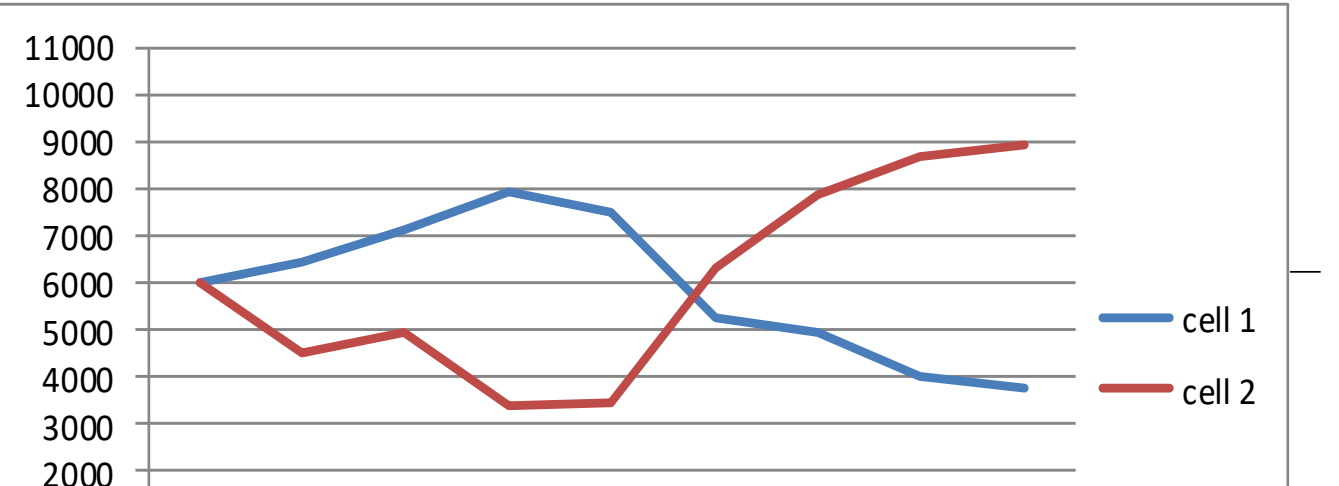


Hypothesis 1b results show that there is no significant difference in the final judgment between subjects who received the information order of good news followed by bad news (cell 3) and subjects who received the information order of bad news followed by good news (cell 4) in the step-by-step presentation pattern and in the framing conditions reversed. This unsupported condition is strengthened by the existence of a fishtail pattern on the revision of participants' beliefs. Hypothesis $1 \mathrm{~b}$ results show that there are no differences in investment decisions. Therefore, the endpoint of the fishtail pattern for hypothesis $1 \mathrm{~b}$ shows an endpoint that is attached or close to each other.

Figure 3

FISHTAIL PATTERNS IN THE REVISION OF CONFIDENCE TAKEN BY INVESTORS ON STEP-BY-STEP PRESENTATION PATTERNS IN INFORMATION

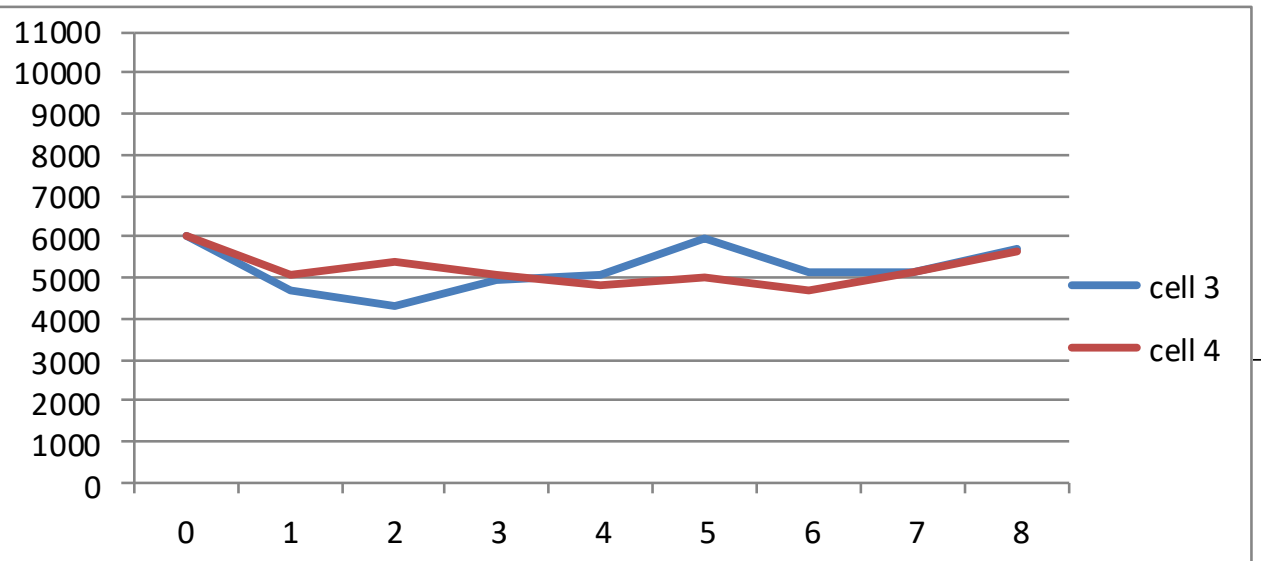


Hypothesis 1c results show that there is no significant difference in the final judgment between subjects who received the information order of good news followed by bad news (cell 5) and subjects who received the information order of bad news followed by good news (cell 6) in the end-of-sequence presentation pattern and in framing conditions in accordance with the information. This unsupported condition is strengthened with a significance value that is greater than 0.05 , which is equal to 0.127. Hypothesis 1d results show that there is no significant difference in the final judgment between subjects who received the information order of good news followed by bad news (cell 7) and subjects who received the information order of bad news followed by good news (cell 8) in the end-of-sequence presentation pattern and in framing conditions reversed. This unsupported condition is strengthened with a significance value that is greater than 0.05, which is equal to 0.477. Hypothesis 2a results indicate that there is a significant difference in the final judgment between subjects who received information with the framing condition in accordance with the information (cell 1) and subjects who received reversed framing (cell 3) in the step-bystep presentation pattern and in the information order of good news followed by bad news. This supported condition is strengthened by the indication of the fishtail pattern in the revision of participants' beliefs. Hypothesis 2a results show that there are differences in investment decisions. Therefore, the endpoints of the fishtail pattern for hypothesis $2 \mathrm{a}$ indicate far endpoints.

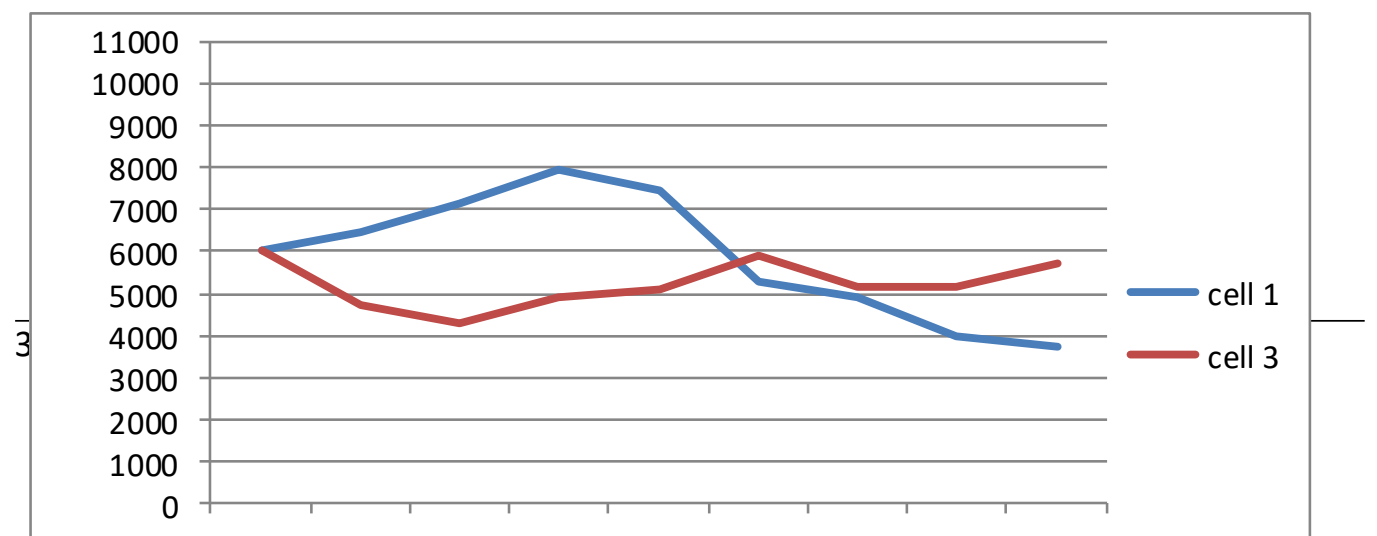




\section{Figure 4}

FISHTAIL PATTERNS IN THE REVISION OF CONFIDENCE TAKEN BY INVESTORS ON STEP-BY-STEP PRESENTATION PATTERNS IN FRAMING EFFECT TESTING

Hypothesis $\mathbf{2 b}$ results show that there is a significant difference in the final judgment between subjects who received information with the framing condition in accordance with the information (cell 2) and subjects who received reversed framing (cell 4) in the step-by-step presentation pattern and in the information order of bad news followed by good news. This supported condition is strengthened by the indication of the fishtail pattern in the revision of participants' beliefs. Hypothesis $2 b$ results show that there are differences in investment decisions. Therefore, the endpoints of the fishtail pattern for hypothesis $2 b$ show far endpoints.

Figure 5

FISHTAIL PATTERNS IN THE REVISION OF CONFIDENCE TAKEN BY INVESTORS ON STEP-BY-STEP PRESENTATION PATTERNS IN FRAMING EFFECT TESTING

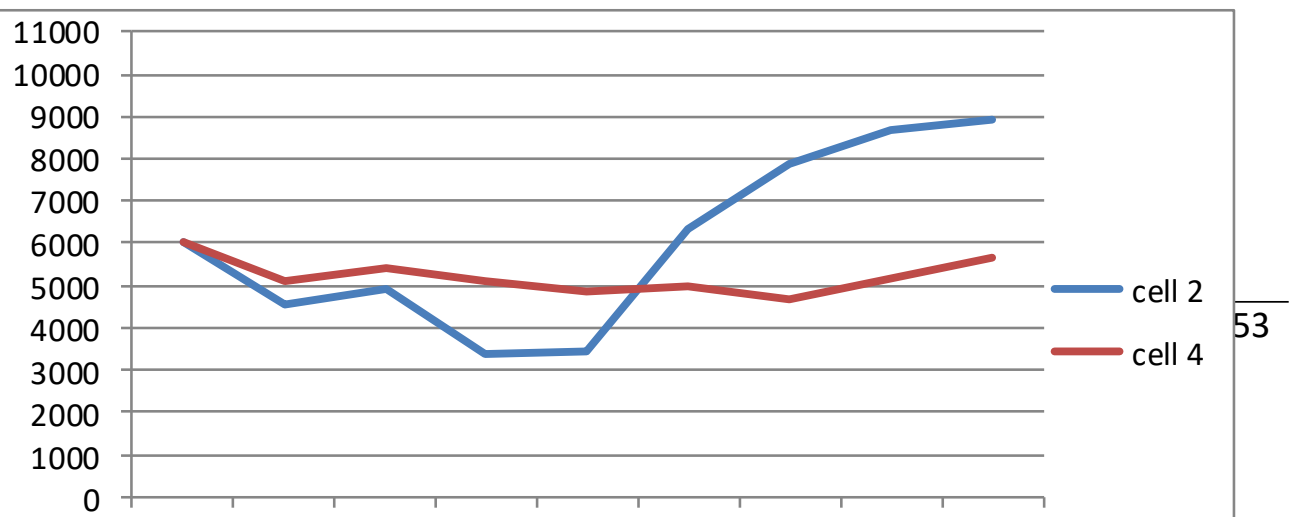


Hypothesis 2c results show that there is no significant difference in the final judgment between subjects who received information with the framing condition in accordance with the information (cell 5) and subjects who received reversed framing (cell 7) in the end-of-sequence presentation pattern and the information order of good news followed by bad news. This unsupported condition is strengthened with a significance value that is greater than 0.05, which is equal to 0.980. Hypothesis $2 \mathrm{~d}$ results show that there is no significant difference in the final judgment between subjects who received information with the framing condition in accordance with the information (cell 6) and subjects who received reversed framing (cell 8) in the end-ofsequence presentation and the information order of bad news followed by good news. This unsupported condition is strengthened with a significance value that is greater than 0.05 , which is equal to 0.839 . Hypothesis 3a results indicate that there is a significant difference in the final judgment between subjects who received information with a step-by-step presentation pattern (cell 1) and subjects who received information with end-of-sequence presentation patterns (cell 5) in the information order of good news followed by bad news and with framing conditions in accordance with the information. This supported condition is strengthened with a significance value that is lower than 0.05, which is equal to 0.012. Hypothesis $\mathbf{3 b}$ results show that there is a significant difference in the final judgment between subjects who received information with a step-by-step presentation pattern (cell 2) and subjects who received information with end-of-sequence presentation patterns (cell 6) in the information order of bad news followed by good news and with framing conditions in accordance with the 
information. This supported condition is strengthened with a significance value that is lower than 0.05, which is equal to 0,000. Hypothesis 3c results show that there is no significant difference in the final judgment between subjects who received information with a step-by-step presentation pattern (cell 3) and subjects who received information with end-of-sequence presentation patterns (cell 7) in the information order of good news followed by bad news and with framing conditions reversed. This unsupported condition is strengthened with a significance value that is greater than 0.05 , which is equal to 0.764 . Hypothesis $3 d$ results show that there is no significant difference in the final judgment between subjects who received information with a step-by-step presentation pattern (cell 4) and subjects who received information with end-ofsequence presentation patterns (cell 8) in the information order of bad news followed by good news and with framing conditions reversed. This unsupported condition is strengthened with a significance value that is greater than 0.05 , which is equal to 0.778 .

\section{Conclusions, Limitations, Suggestions}

The conclusions that can be drawn based on the test results are: first, the findings of this study indicate the occurrence of judgment bias, especially the recency effect on the step-by-step presentation pattern with the framing conditions in accordance with the information. The findings of this study are very important because, generally, the practice in the capital market when investing also uses this pattern, which will undoubtedly lead to biased decision making. Second, there is a judgment bias when the step-by-step presentation pattern is given when the framing conditions are in accordance with the information, and the framing is reversed. The results of this study indicate that individuals are stuck in a framing trap even though the presentation pattern is step by step. Third, when information presentation patterns and framing conditions in accordance with the information are being mixed, there is a judgment bias made by individuals. This shows that there is an influence of the 
framing effect even though the framing used is in accordance with the information.

The overall results of the research show that the belief adjustment model of Hogarth and Einhorn (1992) and the three theories, namely prospect theory, fuzzy trace theory, and probabilistic mental theory partially hold in investment decision making. The prediction of belief adjustment models and the three theories that are not supported in this study are: first, this study failed to provide the support that the SbS presentation pattern would cause a recency effect when receiving a short series of information and with the framing conditions reversed. Secondly, this study failed to provide the support that the EoS presentation pattern would cause a primacy effect when receiving a short series of information and with conditions both of framing in accordance with the information and of framing reversed. Third, this study was unsuccessful in providing the support that the EoS presentation pattern would lead to individuals stuck in a framing trap. Fourth, this study was unsuccessful in providing the support that testing the presentation patterns by providing framing conditions reversed would lead to differences in investment decisions. This study has several limitations in the research presented as follows:

1. There were some participants who were late and thus who required the execution to be delayed from the predetermined schedule.

2. Some participants made a sudden cancellation on their willingness to attend, and that caused the researcher to find other participants' substitutes immediately.

3. The mix design used by the researchers was an information presentation patterns mix design. This caused inaccuracy to see the framing effect.

Based on the research results, conclusions, and limitations in this study expect future researchers to:

1. Schedule the arrival of participants 45 minutes to 1 hour before the execution begins in order to minimize the number of late participants. 
2. We recommend that researchers have spare participants so that it would be easier to find substitutes when participants are making a sudden participation cancellation.

3. Future researchers should use the mix design framing effect so that in future studies, they can show more accurate research results to see the framing effect.

\section{REFERENCES}

Brainerd, C. J., \& Reyna, V. F. 1998. Fuzzy-trace theory and children's false memories. Journal of experimental child psychology, 71(2), 81-129.

Chang, C. J., Yen, S. H., \& Duh, R. R. 2002. An empirical examination of competing theories to explain the framing effect in accounting-related decisions. Behavioral Research in Accounting, 14(1), 35-64.

Christensen, Larry B. 1988. Experimental Methodology. Penerbit Allyu and Bacon Incorporation.

Cox, P., Brammer, S., \& Millington, A. 2004. An empirical examination of institutional investor preferences for corporate social performance. Journal of Business Ethics, 52(1), 27-43.

Erlinda Kusuma Wardani dan Sukirno. 2014. Pengaruh Framing Effect Terhadap Pengambilan Keputusan Investasi dengan Locus of Control sebagai Variabel Pemoderasi. Nominal: Barometer Riset Akuntansi dan Manajemen, 3.1.

Ertambang Nahartyo. 2012. Desain dan Implementasi Riset Eksperimen. Yogyakarta: UPP STIM YKPN.

Gigerenzer, G., Hoffrage, U., \& Kleinbölting, H. 1991. Probabilistic mental models: a Brunswikian theory of confidence. Psychological Review, 98(4), 506.

Hogarth, R. M., \& Einhorn, H. J. 1992. Order effects in belief updating: The belief-adjustment model. Cognitive psychology, 24(1), 1-55.

Imam Ghozali. 2013. Aplikasi Analisis Multivariate dengan Program IBM SPSS 21. Semarang: Badan Penerbit Universitas Diponegoro.

Kahneman, D., \& Tversky, A. 1979. Prospect theory: An analysis of decision under risk. Econometrica: Journal of the econometric society, 263-291.

Kühberger, A. 1995. The framing of decisions: A new look at old problems.Organizational Behavior and Human Decision Processes, 62(2), 230-240. 
Luciana Spica Almilia. 2013. Model Belief Adjustment Dalam Pengambilan Keputusan Investasi Berdasarkan Informasi Akuntansi dan Nonakuntansi. Disertasi tidak dipublikasikan. Universitas Gadjah Mada.

Luciana Spica Almilia, Jogiyanto Hartono, Supriyadi dan Ertambang Nahartyo. 2013. Belief Adjustment Model in Investment Decision Making. Gadjah Mada International Journal of Business, 15:2, $171-182$

Luciana Spica Almilia dan Supriyadi. 2013. Examining belief adjustment model on investment decision making. International Journal of Economics and Accounting, 4.2; 169-183.

Muhammad Nur Yahya dan Jen Surya. 2012. Pengaruh Framing Effect Sebagai Determinan Escalation of Commitment Dalam Keputusan Investasi: Dampak dari Working Experiences. Jurnal Akuntansi, 4.2, 153-164.

Pinsker, R. 2007. Long series of information and nonprofessional investors' belief revision. Behavioral Research in Accounting, 19(1), 197-214.

Pinsker, R. 2011. Primacy or recency? A study of order effects when nonprofessional investors are provided a long series of disclosures. Behavioral Research in Accounting, 23(1), 161-183.

Reyna, V. F., \& Brainerd, C. J. 1990. Fuzzy processing in transitivity development. Annals of Operations Research, 23(1), 37-63.

Sharma, D. S. 2006. Effects of professional and non-professional investors' perceptions of board effectiveness on their judgments: An experimental study. Journal of Accounting and Public Policy, 25(1), 91-115.

Tversky, A., dan D. Kahneman. 1981. The framing of decisions and the psychology of choice. Science 211: 453-458.

Yusnaini. 2005. Analisis Framing dan Causal Cognitive Mapping dalam Pengambilan Keputusan Strategik: Suatu Studi Eksperimental. Simposium Nasional Akuntansi VIII, 9.1. Universitas IBA Palembang. 